\title{
The Relationship Between Media Marketing Advertising and Encouraging Jordanian Women to Conduct Early Detection of Breast Cancer
}

\author{
Ahmad Kamal Alhawamdeh ${ }^{1^{*}} \quad$ Mahmoud Alghizzaw $^{2} \quad$ Mohammed Habes $^{3} \quad$ Motteh S. Alshibly $^{4}$ \\ 1.Faculty Of Business, Economics And Social Development, University Malaysia Terengganu, Kuala \\ Terengganu, Malaysia \\ 2.Faculty of Business and Management Sciences, University Sultan Zainal Abidin, Terengganu, Malaysia \\ 3.Faculty of Faculty of Applied Social Sciences, University Sultan Zainal Abidin, Kuala Terengganu, Malaysia \\ 4.Professor in Faculty of Business and Management Sciences, Amman Arab University, Amman, Jordan.
}

\begin{abstract}
Cancer is a malignant disease, and breast cancer is classified as one of the most critical types of cancer especially for the women. Breast cancer is one of the most prevalent diseases that cause death among respect entity. However, a large proportion of them is unaware of its seriousness and the importance of early breast cancer screening. This study aims to highlight the effects of marketing ads on encouraging Jordanian women to carry out an early examination of breast cancer to attain the goal of the study, the researchers worked on comparing the results of previous studies in this field. Therefore, the results showed that marketing ads have a strong significant effect on encouraging women to early examination. Several resources were used for these marketing advertisements that educate women about early detection of breast cancer. Also, traditional media methods such as radio and television, and modern methods such as the Internet, smartphones, and social media were largely preferred. Moreover, the researchers further suggested that there should be more advertising campaigns that can enhance audience predilection concerning early detection of breast cancer.
\end{abstract}

Keywords: Marketing ads, Females, Breast Cancer, JBCP, Jordan, Media.

DOI: $10.7176 / \mathrm{EJBM} / 12-12-11$

Publication date: April $30^{\text {th }} 2020$

\section{Introduction}

Development of new means of communication has increased competition which is causing higher dependence on marketing advertisements (Alghizzawi, 2019b, 2019a; Habes et al., 2019; Al-Maroof et al., 2020) This study focused on marketing advertisements subjected to encourage Jordanian women for early screening for breast cancer as it is one of the most chronic diseases that threaten the lives of women. Still, the majority of them do not know the importance of early examination of breast cancer. Only through proper knowledge and awareness, they can effectively counteract against this ailment (Al-Mohammad, Akroush and Odetallah, 2014; Bejnordi et al., 2017; Said A Salloum, Maqableh, et al., 2018) When cancer is identified early, it increases the chance of survival significantly higher than late detection. Late detection causes serious consequences and mostly results in sudden death (Organization, 2017). Women with breast cancer in the early stages, live approximately five years more than women who have been discovered in late stages. The more women recover from this disease, the more effectively they take steps for regular examination. This is possible through marketing advertisements in which breast cancer survivors tend to inspire and motivate other women about it. By using marketing advertisements, we can save many lives from breast cancer by spreading immediate awareness. For many experts, advertising can be a controlling mechanism that can motivate the audience for a certain step. It is also confirmed that $58 \%$ of society is influenced by television advertisements regarding their purchasing behaviour (Habes,2019), as advertising contain certain techniques that deeply influence the consumer behaviour (Al-Emran and Salloum, 2017; Salloum et al., 2017; S.A. Salloum et al., 2018).

\section{Methods}

This study is presented as a support of the previous studies that dealt with awareness-raising about breast cancer among women. In the third section of this study, the researchers adopted the comparison approach, in the fourth section the researchers discussed the results and finally in section five conclusion and recommendations are given (Said A Salloum, Al-Emran, et al., 2018; Salloum, Al-Emran, Habes, et al., 2019; Salloum, Al-Emran, Khalaf, et al., 2019).

\section{Literature Review}

Cancer was first discovered in Egypt by archaeologists particularly the bone cancer (Blackadar, 2016). Based on biological science studies, the random growth of cancer cells leads to the generation of a group of tissues called a tumor, and this includes all cancerous diseases, except for leukemia. The human body contains different cells; 
some are important but some are harmful if exist inside the body (Siegel, Naishadham and Jemal, 2012). Breast cancer arises because of the development of malignant cells and their collection in the breast ducts leading to the growth of the disease cells (Collaborators, 2003). The main focus here for the study lies in the fact that many women are reluctant to accept the importance of an early examination as they lack awareness about the fatal consequences of this disease. Therefore, there is a high number of deaths due to the delay in early examination and diagnosing cancer. Focus on marketing advertisements is a motivation to solve this problem, as it has a major role to influence the women (Council, 2001; Kösters and Gøtzsche, 2003; Smith, Cokkinides and Eyre, 2004; Nothacker et al., 2009; Al-Shibly et al., 2019; Black and Richmond, 2019).

\subsection{Marketing Advertisements}

Marketing ads is a set of processes used to create valuable communication between organizations and individuals to achieve a mutual benefit (Calvert, 2008; Al-Shibly and hamdan Alkhawaldeh, 2017). Advertisements have a very important role to link the needs and desires of people with the services and goods to be sold. They affect consumers by informing them about new services, motivating and persuading them according to the nature of the marketed advertisement (Vargas, Duff and Faber, 2017; Zainal, Yousuf and Salloum, 2020) The importance of ads increased with the development of communication channels between individuals, Due to this development. now there are diverse methods for marketing ads, such as smartphones and social media (Alghizzawi et al., 2018, 2019; Alghizzawi, Salloum and Habes, 2018; Habes, Alghizzawi, Khalaf, et al., 2018; Habes, Alghizzawi, Salloum, et al., 2018; Alnawafleh, Alghizzawi and Habes, 2019). According to (Knoll and Proksch, 2017; Habes, Salloum, , et al., 2018; Habes, 2019), an advertisement must create a relationship with the recipient, and this relationship should reflect the importance of the product or service. The functions of marketing advertisements include the marketing tasks that are to meet the needs and desires of individuals (Tumlieh, 2009; Kotler and Armstrong, 2010).

\subsection{Precocious Detection of Breast Cancer}

Cancer screening is a medical examination used to detect the possible occurrence of cancer cells before any symptoms or complaint from the patient. Several scientific studies have shown that early cancer detection helps to reduce the cost of treatment. Early detection also tends to reduce the risk of adverse consequences even death (Smith, Cokkinides and Brawley, 2009). There are several ways to conduct early breast cancer screening initially, through self-examination which is simple and easy. Further, there is a clinical examination, done by a doctor by using "Radiography" as it is the most accurate way to detect any cancerous cells. Finally, we have magnetic resonance and the ultrasound waves that define these Cancerous cells. Table 1 below shows the prevalence of breast cancer among women in Jordan:

Table 1: The most common types of cancer among Jordanian women

\begin{tabular}{|c|c|c|c|c|}
\hline & No & Site & Freq & $\%$ \\
\hline & 1 & Breast & 1263 & 39.7 \\
\hline & 2 & Colorectal & 308 & 9.7 \\
\hline & 3 & Thyroid & 202 & 6.3 \\
\hline & 4 & Corpus Uteri & 134 & 4.2 \\
\hline & 5 & Non-Hodgkin lymphoma & 111 & 3.5 \\
\hline & 6 & Ovary & 96 & 3.0 \\
\hline & 7 & Trachea, Bronchus, Lung & 86 & 2.7 \\
\hline 4 & 8 & Hodgkin disease & 79 & 2.5 \\
\hline & 9 & Brain, Nervous system & 65 & 2.0 \\
\hline & 10 & Stomach & 58 & 1.8 \\
\hline
\end{tabular}

\subsection{Jordan Breast Cancer Program}

The breast cancer program was established in Jordan in 2007, under the surveillance of the Jordanian Ministry of Health. This program was managed by a group of local and international specialists with the World Health Organization (WHO), the United Nations (UN), and Jordanian hospitals. Both the plan of action and implementation of the program were initiated through the King Hussein Cancer Center. The major objective of this scheme was to decrease the death rates from breast cancer among Jordanian women and to diagnose breast cancer during early stages. Through motivational programs, initiatives were taken for Jordanian women regarding breast cancer diagnosis and treatment. The program was focused on five main axes to achieve the designated goals (JBCP, 2017) which are shown in figure (1), figure (2) mentioned below: 


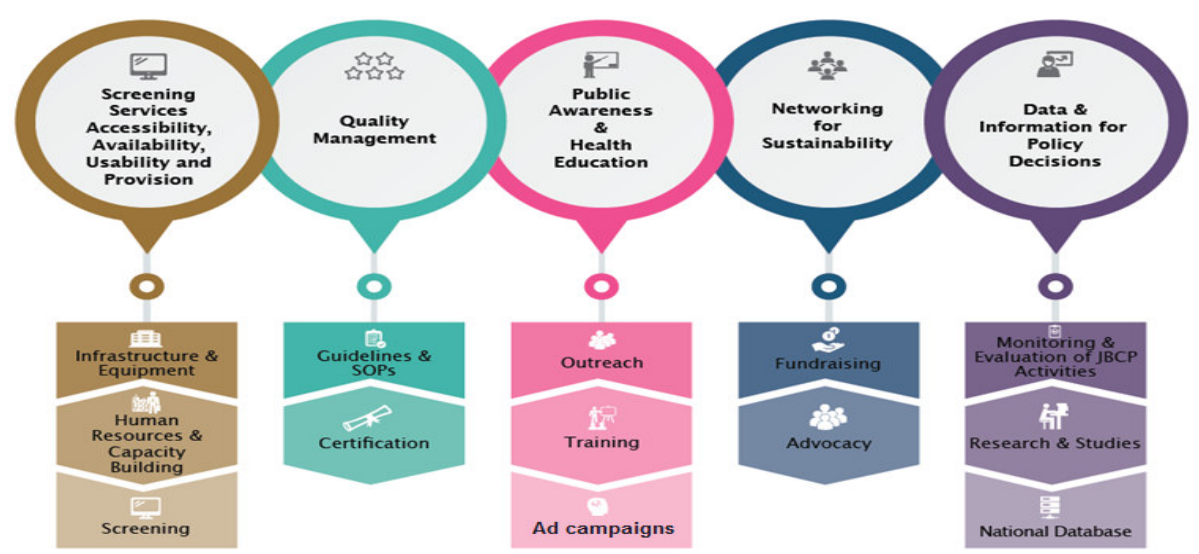

Figure 2: The Five Main axes of Jordan Breast Cancer Program

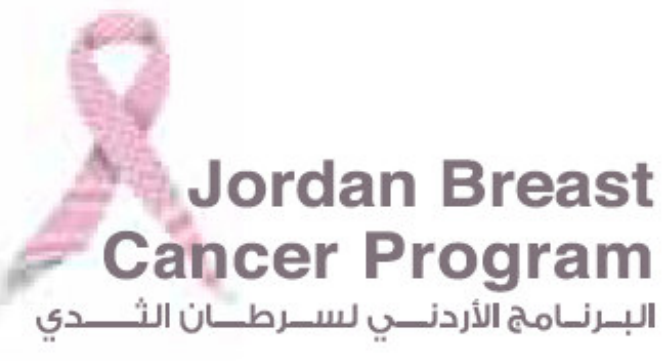

Figure 3: Jordan Breast Cancer Program Logo

\section{Result / Discussion}

Social support motivates women to report any change they have and to work on early screening for breast cancer. But social support alone is not enough without the presence of marketing awareness campaigns especially when there is a majority of uneducated women (Bouskill, 2015; Documet et al., 2015). A study conducted by (Al Rifai and Nakamura, 2015) revealed that there is a positive impact of marketing advertisements highlighting the preeminence of screening for breast cancer. However, relying mainly on these traditional resources is not enough to counteract against the phenomenon. This is because only $10 \%$ of Jordanian women acknowledged and recommended the importance of developing marketing programs. Through modern marketing media, the importance of breast cancer examination is largely highlighted. (Donnelly et al., 2015) examined the role of marketing advertisements concerning early breast cancer screening and diagnosis awareness in Qatar. Results unveiled that due to lack of media marketing awareness concerning breast cancer, the majority of women were unaware of the importance of early screening and diagnosis of breast cancer. Therefore, the researcher suggested that marketing advertisements in Qatar should focus on spreading breast cancer awareness among women so that the growing rate of late detection and deaths may be eliminated. Another study conducted by (Henize, 2013) showed that traditional and modern methods of marketing advertisements are an important factor to spread early screening awareness. Even young women can be also accessed through social media by using special marketing advertisements for early detection of breast cancer (Henize, 2013). A study conducted by (Glynn et al., 2011) confirmed that there are important and positive effects of the marketing advertising campaign on precocious detection of breast cancer. It is possible to use these advertisements for other cancer diseases as well. Increased marketing awareness campaigns on early detection of breast cancer help to raise public awareness. It is also possible by representing celebrities as opinion leaders to encourage women (Jacobsen and Jacobsen, 2011). Results of another study conducted by (Rankova et al., 2010; Alghizzawi, Habes and Salloum, 2019) showed that there is a difference between doctors who specialize in cancer and between the media and public awareness in Thailand. In this regard, the researchers emphasized that Thailand need to begin marketing advertisements about early detection of breast cancer through websites. It is also noted that there is a lack of awareness regarding breast cancer among women. It is important to initiate awareness-raising marketing advertising to save their lives (Frankenfield, 2009; Salloum, Al-Emran and Shaalan, 2017). To effectively raise awareness, the slogan of pink ribbon "Fighting Breast Cancer" can be placed on charitable advertisements and on some products that may contribute to raise awareness and motivate the women for early examination and fight this disease (Brenner, 2009).

\section{Conclusion}

This study is aimed to review the importance of marketing advertisements to educated and encourage Jordanian 
women about the early screening of breast cancer. To achieve the goal of the study, the researchers reviewed the relevant literature that supported the idea of utilizing marketing advertisements to raise awareness concerning early screening. The researcher assumed the strong and significant impacts of these marketing advertisements on Jordanian women as these advertisements have the potential to motivate and persuade them for early screening. These advertisements through both traditional and new media are well capable of influencing women's behavior towards serious health issues like breast cancer. Radio, television, newspaper and today new media technology all are potentially helpful to target the women of every age. In this context, marketing advertisement keeps the women informed about how to tackle this disease. Thus, in the Jordanian context, this topic needs more discussion as people especially women need to be more careful about the prevailing health concerns.

\subsection{Scope \& Recommendation}

Depending on the previous literature, the results will enhance awareness concur the early detection of breast cancer among Jordanian women. This will also guide the Ministry of Health Jordan and the Hussein Cancer Center to adopt new strategies to raise awareness among women. Using media marketing advertisements in future will alter the perceptions and attitudes of the common. This is because breast cancer is briskly spreading among women in Jordan, early screening and diagnosis can help to restrict the growth and rate of deaths. Using mass media as a tool of awareness will help the women to acknowledge and adopt the early screening techniques, developing the characteristics of advertisement campaigns through working extensively to make their advertisement campaigns available frequently throughout the year in order to remind women by early breast cancer screening, this will help them to live a healthy life. In future, researchers in marketing science can address the impact of marketing ads on other sectors besides health and consumer services.

\section{References}

Al-Emran, M. and Salloum, S. A. (2017) 'Students' Attitudes Towards the Use of Mobile Technologies in eEvaluation', International Journal of Interactive Mobile Technologies (iJIM), 11(5), pp. 195-202. doi: 10.3991/ijim.v11i5.6879.

Al-Maroof, R. S. et al. (2020) 'Understanding an Extension Technology Acceptance Model of Google Translation: A Multi-Cultural Study in United Arab Emirates', International Journal of Interactive Mobile Technologies (iJIM), 14(03), pp. 157-178.

Al-Mohammad, S., Akroush, M. and Odetallah, A. L. (2014) 'Marketing culture and business performance', Marketing Intelligence \& Planning. Emerald Group Publishing Limited.

Al-Shibly, M. S. et al. (2019) 'The Impact of De-marketing in Reducing Jordanian Youth Consumption of Energy Drinks', in International Conference on Advanced Intelligent Systems and Informatics. Springer, pp. 427437.1

Al-Shibly, M. S. and hamdan Alkhawaldeh, K. (2017) 'The Impact of Marketing by Relationships to Achieve Competitive Advantage A Case Study" Cellular Telecommunication Companies in Jordan', Journal of Marketing Management, 5(2), pp. 31-43.

Alghizzawi, M. et al. (2018) 'The Impact of Smartphone Adoption on Marketing Therapeutic Tourist Sites in Jordan', International Journal of Engineering \& Technology, 7(4.34), pp. 91-96.

Alghizzawi, M. et al. (2019) 'The effect of social media usage on students'e-learning acceptance in higher education: A case study from the United Arab Emirates', International Journal of Information Technology and Language Studies, 3(3).

Alghizzawi, M., Habes, M. and Salloum, S. A. (2019) 'The Relationship Between Digital Media and Marketing Medical Tourism Destinations in Jordan: Facebook Perspective', in International Conference on Advanced Intelligent Systems and Informatics. Springer, pp. 438-448.

Alghizzawi, M., Salloum, S. A. and Habes, M. (2018) 'The role of social media in tourism marketing in Jordan', International Journal of Information Technology and Language Studies, 2(3).

Alnawafleh, H., Alghizzawi, M. and Habes, M. (2019) 'The impact of introducing international brands on the development of Jordanian tourism', International Journal of Information Technology and Language Studies, $3(2)$.

Bejnordi, B. E. et al. (2017) 'Diagnostic assessment of deep learning algorithms for detection of lymph node metastases in women with breast cancer', Jama. American Medical Association, 318(22), pp. 2199-2210.

Black, E. and Richmond, R. (2019) 'Improving early detection of breast cancer in sub-Saharan Africa: why mammography may not be the way forward', Globalization and health. Springer, 15(1), p. 3.

Blackadar, C. B. (2016) 'Historical review of the causes of cancer', World journal of clinical oncology. Baishideng Publishing Group Inc, 7(1), p. 54.

Bouskill, K. (2015) 'The globalization of the breast cancer Awarenesss campaign in Austria, 2012-2014', Emory University, Atlanta, GA.

Brenner, B. A. (2009) 'Re:"The Power of Pink: Cause-Related Marketing and the Impact on Breast Cancer"', 
Journal of the American College of Radiology. Elsevier, 6(3), p. 215.

Calvert, S. L. (2008) 'Children as consumers: Advertising and marketing', The future of children. JSTOR, pp. 205-234.

Collaborators, M. W. S. (2003) 'Breast cancer and hormone-replacement therapy in the Million Women Study', The Lancet. Elsevier, 362(9382), pp. 419-427.

Council, N. R. (2001) Mammography and beyond: developing technologies for the early detection of breast cancer. National Academies Press.

Documet, P. et al. (2015) 'The association of social support and education with breast and cervical cancer screening', Health Education \& Behavior. Sage Publications Sage CA: Los Angeles, CA, 42(1), pp. 55-64.

Donnelly, T. T. et al. (2015) 'Factors that influence awareness of breast cancer screening among Arab women in Qatar: results from a cross sectional survey', Asian Pacific Journal of Cancer Prevention. Asian Pacific Organization for Cancer Prevention, 15(23), pp. 10157-10164.

Frankenfield, K. M. (2009) 'Health belief model of breast cancer screening for female college students'.

Glynn, R. W. et al. (2011) 'The effect of breast cancer awareness month on internet search activity-a comparison with awareness campaigns for lung and prostate cancer', BMC cancer. Springer, 11(1), p. 442.

Habes, M., Alghizzawi, M., Khalaf, R., et al. (2018) 'The Relationship between Social Media and Academic Performance: Facebook Perspective', International Journal of Information Technology and Language Studies, 2(1).

Habes, M., Salloum, S. A., et al. (2018) 'The role of modern media technology in improving collaborative learning of students in Jordanian universities', International Journal of Information Technology and Language Studies, 2(3).

Habes, M., Alghizzawi, M., Salloum, S. A., et al. (2018) 'The Use of Mobile Technology in the Marketing of Therapeutic Tourist Sites: A Critical Analysis', International Journal of Information Technology and Language Studies, 2(2).

Habes, M. (2019) 'The influence of personal motivation on using social TV: A Uses and Gratifications Approach', International Journal of Information Technology and Language Studies, 3(1).

Habes, M. et al. (2019) 'The Relation Between Social Media and Students' Academic Performance in Jordan: YouTube Perspective', in International Conference on Advanced Intelligent Systems and Informatics. Springer, pp. 382-392.

Henize, S. E. (2013) 'Breast Cancer in the Media: Agenda-Setting and Framing Effects of Prevalent Messages on College-Aged Women'. Bowling Green State University.

Jacobsen, G. D. and Jacobsen, K. H. (2011) 'Health awareness campaigns and diagnosis rates: evidence from National Breast Cancer Awareness Month', Journal of health economics. Elsevier, 30(1), pp. 55-61.

JBCP (2017) Jordan Breast Cancer Program. Amman Jordan.

Khader, Y. S. et al. (2018) 'The Epidemiology and Trend of Cancer in Jordan, 2000-2013', Journal of cancer epidemiology. Hindawi, 2018.

Knoll, J. and Proksch, R. (2017) 'Why we watch others' responses to online advertising-investigating users' motivations for viewing user-generated content in the context of online advertising', Journal of Marketing Communications. Taylor \& Francis, 23(4), pp. 400-412.

Kösters, J. P. and Gøtzsche, P. C. (2003) 'Regular self-examination or clinical examination for early detection of breast cancer', Cochrane Database of Systematic Reviews. John Wiley \& Sons, Ltd, (2).

Kotler, P. and Armstrong, G. (2010) Principles of marketing. Pearson education.

Nothacker, M. et al. (2009) 'Early detection of breast cancer: benefits and risks of supplemental breast ultrasound in asymptomatic women with mammographically dense breast tissue. A systematic review', BMC cancer. Springer, 9(1), p. 335.

Organization, W. H. (2017) 'Guide to cancer early diagnosis'. World Health Organization.

Rankova, A. Z. et al. (2010) 'Promoting Awareness and Early Detection of Breast Cancer in Thailand'. Worcester Polytechnic Institute.

Al Rifai, R. and Nakamura, K. (2015) 'Differences in breast and cervical cancer screening rates in Jordan among women from different socioeconomic strata: Analysis of the 2012 population-based household survey', Asian Pac J Cancer Prev, 16(15), pp. 6697-6704.

Salloum, S. A. et al. (2017) 'Analysis and Classification of Arabic Newspapers' Facebook Pages using Text Mining Techniques', International Journal of Information Technology and Language Studies, 1(2), pp. 8-17.

Salloum, Said A, Al-Emran, M., et al. (2018) 'Factors affecting the E-learning acceptance: A case study from UAE', Education and Information Technologies. Springer, pp. 1-22.

Salloum, Said A, Maqableh, W., et al. (2018) 'Studying the Social Media Adoption by university students in the United Arab Emirates', International Journal of Information Technology, 2(3), pp. 83-95.

Salloum, S.A. et al. (2018) 'Using text mining techniques for extracting information from research articles', in Studies in Computational Intelligence. Springer. doi: 10.1007/978-3-319-67056-0_18. 
Salloum, S. A., Al-Emran, M., Khalaf, R., et al. (2019) 'An Innovative Study of E-Payment Systems Adoption in Higher Education: Theoretical Constructs and Empirical Analysis.', International Journal of Interactive Mobile Technologies, 13(6).

Salloum, S. A., Al-Emran, M., Habes, M., et al. (2019) 'Understanding the Impact of Social Media Practices on E-Learning Systems Acceptance', in International Conference on Advanced Intelligent Systems and Informatics. Springer, pp. 360-369.

Salloum, S. A., Al-Emran, M. and Shaalan, K. (2017) 'Mining Social Media Text: Extracting Knowledge from Facebook', International Journal of Computing and Digital Systems, 6(2), pp. 73-81. doi: $10.12785 / \mathrm{ijcds} / 060203$.

Siegel, R., Naishadham, D. and Jemal, A. (2012) 'Cancer statistics, 2012', CA: a cancer journal for clinicians. Wiley Online Library, 62(1), pp. 10-29.

Smith, R. A., Cokkinides, V. and Brawley, O. W. (2009) 'Cancer screening in the United States, 2009: a review of current American Cancer Society guidelines and issues in cancer screening', CA: a cancer journal for clinicians. Wiley Online Library, 59(1), pp. 27-41.

Smith, R. A., Cokkinides, V. and Eyre, H. J. (2004) 'American Cancer Society guidelines for the early detection of cancer, 2004', CA: a cancer journal for clinicians. Wiley Online Library, 54(1), pp. 41-52.

Tumlieh, E. F. A. (2009) Marketing in Small enterprises, Strategic Introduction. Amman, Jordan: Al-Manahij House for Publishing and Distribution.

Vargas, P. T., Duff, B. R. L. and Faber, R. J. (2017) 'A practical guide to experimental advertising research', Journal of Advertising. Taylor \& Francis, 46(1), pp. 101-114.

Zainal, A. Y., Yousuf, H. and Salloum, S. A. (2020) 'Mining social media text: extracting knowledge from Facebook', in Joint European-US Workshop on Applications of Invariance in Computer Vision. Springer, pp. $762-772$. 